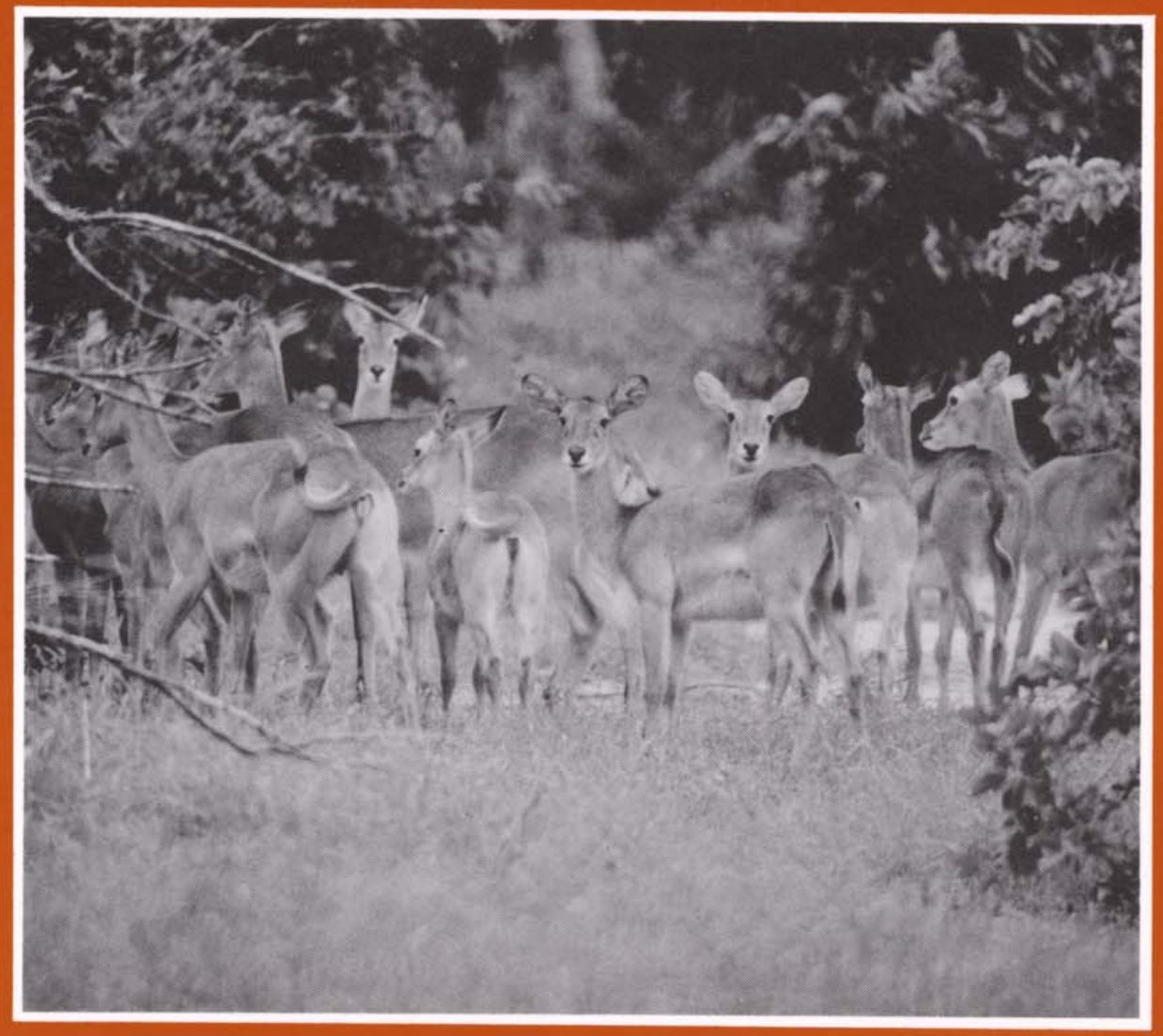

Action Strategy for Protected Areas in the Afrotropical Realm

Prepared during the 28th Working Session of IUCN's Commission on National Parks and Protected Areas "W" National Park, Niger, 17-21 March 1987 


\title{
ACTION STRATEGY FOR PROTECTED AREAS IN THE AFROTROPICAL REALM
}

\author{
Commission on National Parks and Protected Areas (CNPPA) \\ International Union for Conservation \\ of Nature and Natural Resources (IUCN)
}

(aussi disponible en français)

June 1987 
Published by IUCN, Gland, Switzerland and Cambridge, UK

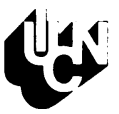

Copyright: $\quad 1987$ International Union for Conservation of Nature and Natural Resources

Reproduction of this publication for educational or other non-commercial purposes is authorized without prior permission from the copyright holder.

Reproduction for resale or other commercial purposes is prohibited without the prior written permission of the copyright holder.

Citation: IUCN, 1987. Action Strategy for Protected Areas in the Afrotropical Realm. IUCN, Gland, Switzerland and Cambridge, UK. 56 pp.

ISBN: $\quad 2-88032-920-5$

Printed by: $\quad$ Parchment (Oxford) Ltd, UK

Cover design by: James Butler

Cover photo: $\quad$ Kob in "W" National Park, Niger: John Newby

Available from: IUCN Publications Services,

219c Huntingdon Road, Cambridge CB3 ODL, UK

or Avenue du Mont-Blanc, CH-1196 Gland, Switzerland

The designations of geographical entities in this book, and the presentation of the material, do not imply the expression of any opinion whatsoever on the part of IUCN concerning the legal status of any country, territory, or area, or of its authorities, or concerning the delimitation of its frontiers or boundaries. 


\section{TABLE OF CONTENTS}

Page

Introduction

The approach

Acknowledgements

PART A: GENERAL REQUIREMENTS FOR CONSERVATION OF 5 PROTECTED AREAS IN AFRICA

Goal 1 The establishment of a representative network of protected areas within the Afrotropical Realm

Goal 2 The development of management capability

Goal 3 Development of national protected area policies which are socially acceptable and integrated into national development as a whole

Goal 4 Strengthen regional cooperation in the development

Goal 5 Monitor the implementation of the action strategy

PART B: AFROTROPICAL COUNTRY PRIORITIES FOR ACTION ON PROTECTED AREAS

\section{Page}

Angola

Benin

Botswana

Burkina Faso

Burundi

Cameroon

Central African Republic

Chad

Comoros

Congo

Djibouti

Equatorial Guinea

Ethiopia

Gabon

Gambia

Ghana

Guinea

Guinea Bissau

Ivory Coast

Kenya

Lesotho

Liberia

Madagascar

Malawi

\section{7}

Mali

Mauritania

Mauritius

Mozambique

Namibia

Niger

Nigeria

Réunion

Rwanda

Sao Tomé and Principe

Senegal

Seychelles

Sierra Leone

Somalia

South Africa

Sudan

Swaziland

Tanzania

Togo

Uganda

Zaire

Zambia

Zimbabwe 


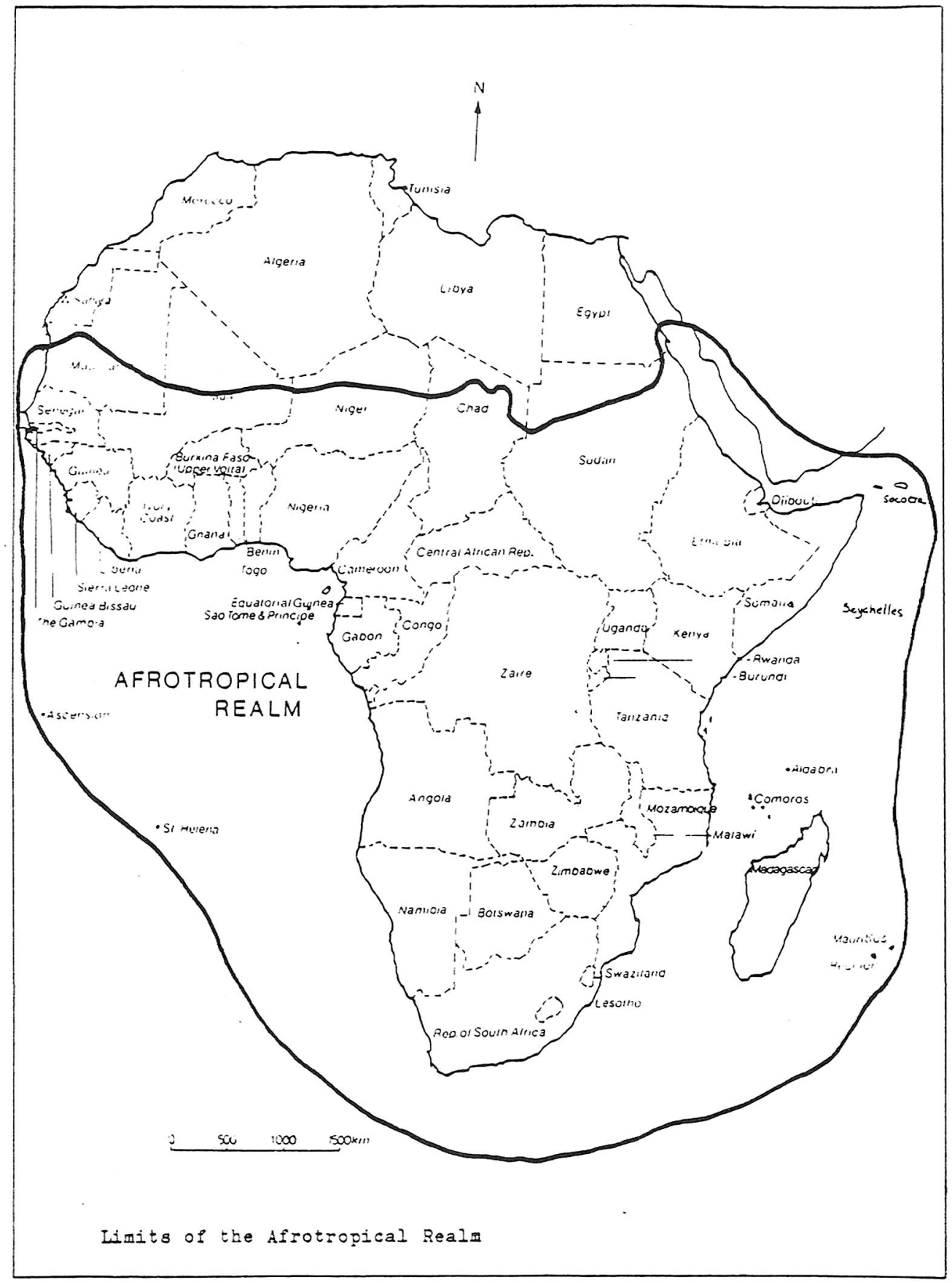




\section{ACTION STRATEGY FOR PROTECTED AREAS \\ IN THE AFROTROPICAL REALM}

\section{INTRODUCTION}

The 1985 UN List of National Parks and Protected Areas notes that there are over 88 million ha of land included in 426 protected areas in the Afrotropical Realm. This amounts to $4.4 \%$ of the area of the Realm. Virtually every African country has established protected areas as a tool for conservation and development and a further 20 million ha are being considered for additions to the system.

But development activities which took industrialized countries many centuries to achieve are being telescoped into a few decades in Africa. This is coupled with rapid population growth, poverty, and recurring drought. As most of the economies are agricultural, there is a scramble for every piece of land to be put into production. In the process, the values of natural ecosystems are of ten overlooked and undervalued.

The need for concrete action and a unified perspective is addressed in this Action Strategy. This document was developed to provide a regional overview of actions needed to more effectively plan and manage protected areas of the Afrotropical Realm over the next few years. It is an action plan developed from the "ground up" - as it was prepared by field managers of Africa's protected areas at working sessions of IUCN's Commission on National Parks and Protected Areas and through correspondence over a six-month period. The Action Strategy is designed by and for countries in the region and spells out both general guidelines for action as well as some specific requirements for each country.

The Action Strategy builds on and extends the regional programme for IUCN support to protected areas initiated during CNPPA's 22nd Working Session in Zimbabwe in May 1983. It incorporates the major recommendations made in the IUCN/UNEP Review of the Protected Areas System in the Afrotropical Realm (1987) compiled by consultants John and Kathy MacKinnon. Marine and coastal inputs are abstracted from previous work carried out by IUCN and UNEP under the East and West African Regional Seas Programmes.

\section{THE APPROACH}

Effective action on protected areas must be initiated and carried out by the nations directly involved. Therefore, the first set of recommended actions under each objective of this Action Strategy is directed to governments and non-governmental conservation organizations in the nations of the Afrotropical Realm. Together, these actions form a checklist of necessary actions to improve the management of protected areas in any country. 
Based on what action is required from governments, priorities are then identified for supporting action by international conservation agencies, including IUCN, WWF, UNEP, Unesco, FAO, EEC, OAU, World Bank, bilateral assistance agencies, and many others. The plan is also addressed to the national parks authorities of the countries outside the region which are making significant contributions to their counterpart agencies in the Afrotropical Realm.

This Action Strategy complements and reinforces the Bali Action Plan and the Action Plan for Biosphere Reserves, with actions designed for the specific conditions in the Afrotropical Realm. Some countries already have national action plans for protected areas and are well advanced with implementation of some of the activities suggested here. But other countries may not have such plans or may face other obstacles. This Action Strategy provides the direction and the general guidelines for action, which will then need to be modified for the specific requirements of each country's development planning process.

Ultimately, it is the people of a country who will decide the scope of conservation activities. Conservation measures which are socially unacceptable to a majority of the population will eventually fail, so there is an urgent need to increase education and extension programmes, especially in conflict zones. Negative impacts need to be lessened and conservation benefits need promotion. It is perhaps this aspect of conservation planning - the human dimension - which requires the greatest thrust in years to come, especially in the Afrotropical Realm, where dense rural populations are still dependent on many wild living natural resources.

These living natural resources are a common heritage to mankind - they have values at local, national and international levels. The exploitation of these resources is being greatly accelerated by the process of economic development, of ten aided by financial support from international sources. It is, therefore, necessary that international cooperation also be directed toward achieving conservation aims. This will be most effective for well-planned projects which clearly emphasize improvement of the quality of human existence as part of protected areas management.

\section{ACKNOWLEDGEMENTS}

The first draft of this plan was compiled by Walter Lusigi, CNPPA's Realm Vice-Chairman for Africa, and Jim Thorsell of the IUCN Secretariat in Switzerland, with inputs from other members of the Programme and Policy Division and staff of the Conservation Monitoring Centre in Cambridge. It was first presented to the International Symposium on African Wildlife meeting in Uganda in December 1986. The second draft was given an intensive review during the 28th Working Session of CNPPA held in Niger in March 1987, when inputs from Park Directors from 11 francophone African countries and others were incorporated. 
In addition to circulation of the draft to over 100 participants at these two meetings, CNPPA members in 38 African countries received copies by mail. Most responded with many useful suggestions and this third and final draft as compiled by the CNPPA office in Switzerland is much improved as a result of this feedback.

IUCN is grateful for the support of the World Wide Fund for Nature (WWF), and the World Heritage Fund in sponsoring the Niger Working Session and for providing funds to publish this Action Strategy. As much of the background material was provided in the IUCN/UNEP report Review of the Protected Areas System in the Afrotropical Realm we are also indebted to UNEP for this contribution. 


\section{GENERAL REQUIREMENTS FOR CONSERVATION OF PROTECTED AREAS IN AFRICA}

\section{GOAL 1 THE ESTABLISHMENT OF A REPRESENTATIVE NETWORK OF PROTECTED AREAS WITHIN THE AFROTROPICAL REALM}

\section{OBJECTIVE 1.1. TO USE MODERN BIOGEOGRAPHIC CONCEPTS TO PREPARE REVIEWS OF NATURAL HABITATS AND ECOLOGICAL COMMUNITIES WITHIN EACH NATION AND DETERMINE THE ADEQUACY OF PROTECTED AREA COVERAGE.}

\section{Activities at the National Level}

1.1.1. Using the currently accepted biogeographic zonation for the country, map the major habitats and their faunal and floral communities, including the locations of centres of endemism and areas of exceptional species and community diversity. (Action: Forestry, Wildlife and Fishery Departments, National MAB Committees)

1.1.2. Prepare inventories of key species in each biogeographic unit and in each protected area.

1.1.3. Determine whether the habitats and fauna in the country, especially centres of endemism and areas of high diversity, have adequate and viable conservation status, and identify gaps and possible surpluses in the national reserve system.

1.1.4. Determine whether existing protected areas are large enough and are receiving appropriate management to fulfil their protective role. Determine if some reserves are redundant and no longer serving a conservation role, or cannot be rehabilitated.

1.1.5. Determine where additional protected areas are required and take steps to establish such areas; and identify areas where conservation measures need to be implemented or strengthened.

\section{Activities at the International Level}

1.1.6. Disseminate widely the Review of the Protected Areas System in the Afrotropical Realm in order to provide the broader framework and methodology for national action. (Action: IUCN, UNEP) 
1.1.7. Continue to develop the database on protected areas by continual updating of IUCN's Directory of Afrotropical Protected Areas. (Action: IUCN)

1.1.8. Provide the necessary information and other forms of support to governments to enable them to assess the adequacy of their protected area coverage. (Action: IUCN, WWF, Unesco, FAO, others)

1.1.9. Promote action by governments as a follow-up to the Review of the Protected Areas System in the Afrotropical Realm and the IUCN Directory of Afrotropical Protected Areas. (Action: IUCN, WWF, OAU, UNEP, NGOs)

1.1.10. Promote collaboration by governments in developing a marine and coastal biogeographical classification system which could be used throughout the Realm, at a scale which would be meaningful for assessing national coverage and protecting biological diversity. (Action: IUCN)

OBJECTIVE 1.2. TO ENSURE ADEQUATE CONSERVATION STATUS FOR UNDER-REPRESENTED BIOLOGICAL COMMUNITIES.

\section{Activities at the National Level}

1.2.1. From objective 1.1 above, give priority for on-the-ground action to biomes, habitats, and areas considered under-represented so that suitable areas can be protected. Areas which require urgent attention are the four least represented of Africa's 17 phytochoria: Guinea-Congolian; Afromontane, and East and West Malagasy (specific sites are identified in Part B).

1.2.2. Focus attention on protecting coastal and marine habitats, including identifying important areas, developing the administrative structures to manage them, and devising appropriate management methodologies for these highly productive areas. Areas requiring immediate attention include:

- Ras Tenewi (proposed national park), Kenya

- Dugong, coral reef and turtle reserves, Somalia

- Dahlak Islands, Ethiopia

- Bijagos Islands, Guinea-Bissau

- Rufiji Delta, Tanzania

- Sanganeb Atoll, Sudan

- Turtle nesting beaches, South Bioko, Equatorial Guinea

- Bazaruto Marine National Park, Mozambique

- Inhaca Island, Mozambique 
- Aldabra Reserve, Seychelles

- Grand Recif and Tulear, Madagascar

- Proposed marine reserves in the Comoros and Mayotte Islands.

1.2.3. Ensure that delegations to meetings of UNEP Regional Seas Programmes are fully briefed on the role of coastal and marine protected areas, and are prepared to support action in this field.

\section{Activities at the International Level}

1.2.4. Make available to national conservation agencies the concepts, information, and expertise required to provide enhanced protection to key habitats, including islands, coastal and marine habitats, wetlands and mountains. (Action: IUCN, WWF, Unesco, UNEP)

1.2.5. Identify how protected areas can contribute to the conservation needs of the inland lake systems at Lakes Malawi, Victoria, Tanganyika, Tumba and Mai-Ndombe in the Zaire basin, and the crater lakes of Cameroon.

1.2.6. Disseminate data on important wetlands in the Realm, contained in the Directory of Afrotropical Wetlands, and maintain the database created for this directory.

1.2.7. Assist in implementing new approaches and measures to manage key wetland sites in the Realm including:

- Swamps of the Sudd, Sudan

- Conkouati mangroves, Congo

- Okavango swamps, Botswana

- Bangweulu swamp, Zambia

- Niger River mangroves and delta

- Banc d'Arguin, Mauritania

- Sherbro River mangroves, Sierra Leone

- Upemba swamps, Zaire

- Kafue floodplains, Zambia

- Lake Chad

1.2.8. Provide a framework for international action on island, coastal and marine protected areas through the UNEP Regional Seas Programme (East Africa, West Africa regional seas). 
OBJECTIVE 1.3. TO ENSURE THAT RELEVANT CATEGORIES OF PROTECTED AREAS ARE GIVEN LEGAL PROTECTION AT AN APPROPRIATE LEGISLATIVE LEVEL.

\section{Activities at the National Level}

1.3.1. Examine national legislation to see if the relevant IUCN Management Categories are mentioned and receive appropriate legal recognition.

1.3.2. Give priority to setting up a network of strictly protected areas (Category I - Strict Nature Reserves) within each major habitat or biotic community, possibly based on zones within existing reserves.

1.3.3. Examine the management status and objectives of existing parks, sanctuaries and other reserves to see if their designated category is providing the appropriate level of protection.

1.3.4. Each relevant government agency should select outstanding areas of biological and natural value for nomination to the World Heritage List, taking into account the possibilities for trans-frontier sites.

1.3.5. Provide necessary support for MAB activities, particularly by forming or activating MAB National Committees, implementing the Biosphere Reserve Action Plan, and establishing Biosphere Reserves which may be included in the international network.

\section{Activities at the International Level}

1.3.6. Provide advice to governments on request on legislation, regulations, and other administrative measures to establish the full range of categories of protected areas, including biosphere reserves. (Action: IUCN's Environmental Law Centre and Commission on Environmental Policy, Law, and Administration).

1.3.7. Provide a framework for international cooperation through the World Heritage Convention and the Biosphere Reserve programme, and provide relevant support to governments for preparing indicative inventories and strengthening field action in World Heritage properties and biosphere reserves. (Action: Unesco, with support from IUCN and UNEP)

1.3.8. Assist in the preparation of projects for submission to the World Heritage Committee for funding. (Action: Unesco, CNPPA)

1.3.9. Support implementation of protected area provisions in regional conventions and protocols related to the marine environment. (Action: UNEP/OCAPAC) 

PROTECTED AREAS

OBJECTIVE 2.1. TO ENSURE THAT EACH NATION HAS STRONG AND EFFECTIVE WILDLIFE CONSERVATION AUTHORITIES AT THE CENTRAL AND STATE OR PROVINCIAL LEVELS SO THAT THE NETWORK OF CONSERVATION AREAS CAN BE ADEQUATELY MANAGED.

\section{Activities at the National Level}

2.1.1. Develop a strong central authority for conservation/wildlife management at both the administrative and technical levels. This should include specialist technical of ficers dealing with management planning, field staff supervision, training, research and monitoring, education/interpretation, wildlife health, and captive breeding and zoos, to ensure adequate inputs at state and field levels.

2.1.2. Develop distinct wildlife/conservation departments with appropriate internal career structures.

2.1.3. Recruit dedicated and highly motivated staff at all professional levels within these departments, and provide adequate salaries and opportunities for advancement within the system.

2.1.4. Ensure that living conditions for field staff include adequate social services.

\section{Activities at the International Level}

2.1.5. Provide support to training efforts, through workshops, fellowships, curriculum development, training manuals, and consultancies. (Action: FAO, Unesco, WWF, IUCN)

2.1.6. Ensure attendance at the International Seminars on National Parks Management and Marine and Coastal Planning by senior park staff from the Realm and encourage application and adaptation of the lessons learned. (Action: WWF, Unesco, NOAA, IUCN, USNPS, FAO)

2.1.7. Provide follow-up action to assessments of regional training needs and manpower planning. (Action: FAO) 

MEET MANPOWER NEEDS.

\section{Activities at the National Level}

2.2.1. Designate a specialized national or regional training institution for senior and middle professional-level protected area staff for both angloand francophone Africa.

2.2.2. Encourage and promote the teaching of wildlands management and conservation at university or other appropriate level. There is a particular need for an academic centre for advanced studies in resource management in francophone Africa.

2.2.3. Develop suitable in-service training programmes with an emphasis on practical field techniques for field and technical staff.

2.2.4. Broaden existing curricula at Garoua and Mweka Colleges to provide courses on social and economic aspects of protected area management.

\section{Activities at the International Level}

2.2.5. Sponsor workshops on management planning, including the demonstration of management planning methodology based on the Sapo National Park (Liberia) experience as a model. (Action: IUCN, UNEP, World Heritage, WWF) Priority areas include:

- Serengeti National Park, Tanzania

- Luangwa Valley National Park, Zambia

- Salonga National Park, Zaire

- Queen Elizabeth National Park, Uganda

- Taï National Park, Ivory Coast

- Outamba-Kilimi National Park, Sierra Leone

- Workshops on the role of protected areas in management of wetlands, islands, and coastal and marine protected areas.

2.2.6. Encourage universities in developed countries to sponsor short courses in conservation (following the example of Montpellier University in France). 


\section{Activities at the National Level}

2.3.1. Document the values and objectives of each protected area so as to specify clearly the purpose of its protection status.

2.3.2. Draw up management plans to protect, perpetuate, and/or rehabilitate these specific values.

2.3.3. Formulate specific management policies for buffer areas surrounding the protected areas, and for adjacent lands not receiving buffer zone status to ensure local people receive direct benefits.

2.3.4. Introduce the necessary enabling legislation and regulations, if they are not already in existence; or revise existing legislation as required.

2.3.5. Develop special programmes for managing livestock, collecting forest products, and wildlife hunting around protected areas.

\section{Activities at the International Level}

2.3.6. Identify a few protected areas in each country representing a range of management categories as "Demonstration Protected Areas", where special support will be provided in terms of equipment, management, education, training, etc. Possibilities include:

- Inhaca Island Marine Reserve, Mozambique

- Mt. Elgon Forest Reserve, Uganda

- Gola Forest and Tiwai Island, Sierra Leone

- Ngorongoro Conservation Area, Tanzania

- Mt. Kulal Biosphere Reserve, Kenya

- Bwindi Forest Reserve, Uganda

- Nazinga Game Ranch, Burkina Faso

- East Usambara Forest Reserves, Tanzania

- Proposed Aïr Ténéré Reserve, Niger

- Bale Mountains National Park, Ethiopia

- Zahamena Reserve, Madagascar

- Sapo National Park, Liberia

- Luki Forest Reserve, Zaire

- Volcanoes National Park, Rwanda

- Saloum Delta, Senegal/Naimi National Park, Gambia

- Mt. Nimba Reserves, Guinea/Ivory Coast

- Marine areas identified as priorities in the East and West African Regional Seas Programmes. 
OBJECTIVE 2.4. TO PROVIDE EACH MANAGEMENT UNIT WITH SUFFICIENT RESOURCES TO IMPLEMENT MANAGEMENT ACTIVITIES IN THE FACE OF INCREASING THREAT TO THESE AREAS.

\section{Activities at the National Level}

2.4.1. Provide empirical documentation to persuade planning and finance ministries that conservation areas need adequate staff, funds, equipment and other resources for their long term survival, and to ensure that they are contributing to rural development in appropriate ways.

2.4.2. National governments should provide operational resources - vehicles, boats, radios, aircraft, equipment, staff - as necessary.

2.4.3. Develop specialized teams in such areas for anti-poaching, dealing with wildlife problems, planning, and extension services at the appropriate local level to assist the limited resources of individual areas.

2.4.4. Encourage the valued inputs from conservation NGOs to supplement the activities of governments.

2.4.5. Promote coordination of intergovernmental and multi-lateral technical assistance efforts in support of protected area projects. (Action: IUCN)

\section{Activities at the International Level}

2.4.6. Compile and maintain a register of protected areas under special threat. (Action: IUCN)

2.4.7. Provide translations of key published materials (e.g. IUCN/UNEP's Managing Protected Areas in the Tropics) in French language editions. (Action: EEC, Government of France)

\section{OBJECTIVE 2.5. TO DEVELOP THE CAPABILITY TO CARRY OUT RESEARCH AND MONITORING ACTIVITIES IN PROTECTED AREAS, AND TO APPLY THE RESULTS TO IMPROVING MANAGEMENT.}

\section{Activities at the National Level}

2.5.1. Create a specialized research coordination post at the central level to actively promote much greater research involvement and the provision of adequate funds for research promotion; or develop other means of promoting research, such as publishing an official "List of Research Priorities in Protected Areas" for the country. 
2.5.2. Develop strong field-oriented research centres in the ecological and socio-economic sciences, possibly in collaboration with universities, research institutes, etc.

2.5.3. Develop appropriate research and monitoring capability directly related to management needs within each major protected area, including adequate staff, equipment, funding, career advancement, etc.

2.5.4. Ensure that relevant research results are employed in the development of improved management procedures.

\section{Activities at the International Level}

2.5.5. Support and work through existing local research institutions such as the Uganda Institute of Ecology, Serengeti Wildlife Research Institute, Moi University, and the Centre de Recherche Scientifique de Taï. (Action: EEC, Unesco, bilateral agencies)

2.5.6. Ensure that results of research bring out management implications and are made locally available at a central location.

2.5.7. Promote appropriate means of dissemination of research findings from protected areas in the Afrotropical Realm, including wider distribution of the African Journal of Ecology, PARKS, Nature et Faune, Banco, Pachyderm, and other relevant journals.

2.5.8. Organize workshops on research priorities, planning, and research methodology appropriate to the Afrotropical Realm.

GOAL 3 DEVELOPMENT OF NATIONAL PROTECTED AREA POLICIES WHICH ARE SOCIALLY ACCEPTABLE AND INTEGRATED INTO NATIONAL DEVELOPMENT AS A WHOLE.

OBJECTIVE 3.1. TO PROMOTE WILDLAND CONSERVATION WITHIN THE
FRAMEWORK OF ALL NATURAL RESOURCE
MANAGEMENT (SOIL, AIR, WATER AND BIOLOGICAL
VALUES) AT THE NATIONAL AND LOCAL LEVELS AND
TO PROMOTE THE LINK BETWEEN CONSERVATION AND
DEVELOPMENT AS LAID DOWN BY THE WORLD
CONSERVATION STRATEGY.

\section{Activities at the National Level}

3.1.1. Ensure that protected area considerations are built into national conservation strategies and in development planning activities. 
3.1.2. Promote the concepts and values of conservation at all possible national fora and levels, including increased use of the news media and educational facilities.

\section{Action at the International Level}

3.1.3. Organize seminars and workshops for donors, administrators and decision makers in which World Conservation Strategy concepts are discussed and action agreed for their implementation.

3.1.4. Document cases where effective management of protected areas has led to tangible benefits for local people and sustainable development for the nation, and disseminate this documentation widely. Examples include:

- Recovery of wildlife populations and habitat restoration in Aïr/Ténéré (proposed National Reserve), Niger;

- Lessening of seasonal damage to crops outside the boundary of Shimba Hills National Reserve (Kenya) following erection of electric fence along portion of park boundary;

- Improved quality of life for peripheral villages at Chirisa Safari Area, Zimbabwe;

- Involving local fishing communities in Saloum Delta National Park, Gambia;

- Environmental awareness enhanced at Marsabit National Reserve, Kenya;

- Improved dry season stream flow from Kasungu National Park, Malawi;

- Regional planning for ecodevelopment in the Inner Niger Delta, Mali;

- Ethiopia's parks and reserves as sources of germplasm for national crop improvement programmes;

- Protection of fish stocks in Banc D'Arguin National Park, Mauritania;

- Tourism development in the Okavango, Botswana;

- Public education at Volcanoes National Park, Rwanda;

- Tourism development and conservation awareness at Djoudj National Park, Senegal;

- Turtle management in the Seychelle Islands;

- Marine resources replenishment in the Malindi and Watamu Marine National Parks, Kenya;

- Local involvement in Kafue Flats/Bangweulu Basin wetland project, Zambia.

3.1.5. Provide expertise and support to NCS activities in Tanzania, Togo, Sierra Leone, Guinea Bissau, Uganda, Ivory Coast, Niger, Madagascar, Zambia and Botswana, and ensure that protected area elements are fully included in the strategies. (Action: IUCN and development agencies) 
3.1.6. Provide international support for national and local conservation awareness activities, particularly:

- Support to ongoing awareness activities, including nature clubs, nature camps, and wildlife clubs; (Action: AWF, NYZS, WWF)

- Preparation of audio-visual packages suitable for decision makers, and for others at different levels (visuals with scripts in local languages which can be communicated by the equipment operators in the local language will be required);

- Provision of sturdy projection equipment and means of transportation;

- Training of qualified and motivated personnel, particularly operators, to conduct a.v. programmes, primarily in rural areas;

- Support provision of relevant film and video material from BBC, Survival Anglia, National Geographic, etc. to the Afrotropical Realm, including making scripts available in the local languages.

3.1.7. Support the efforts of the Governments of Zambia and Tanzania to prepare regional land-use management schemes; including a series of protected areas, for the Luangwa Valley and the Serengeti region. (Action: IUCN, WWF, NORAD)

OBJECTIVE 3.2. TO RECOGNIZE POPULATION GROWTH AND INCREASED PRESSURE ON LAND AS MAJOR FACTORS AFFECTING PROTECTED AREAS AND TO SUPPORT NATIONAL POLICIES AIMED AT REGULATING THESE FACTORS.

\section{Activities at the National Level}

3.2.1. Support national population policies by providing data, case histories and ecological arguments to promote population stability, sustainable land use, and re-settlement policies.

3.2.2. Develop sound and convincing arguments which demonstrate that protecting critical natural areas helps support food production outside these areas, through watershed protection, soil formation, micro-climate amelioration, genetic resources, meat production on marginal lands, fishery stocks, etc.

3.2.3. Develop special training courses on conservation for extension and social workers who deal directly with human welfare, particularly around protected areas.

\section{Activities at the International Level}

3.2.4. Assist in promotion of informed population policies in publications, and discussions dealing with natural resource conservation. 
3.2.5. Endorse financial support for international organizations dealing with population issues, such as IPPF, Unicef, World Population Council, etc. (Action: all international agencies and donor governments)

3.2.6. Promote applied research into human ecology in areas of importance for conservation, including such areas as:

- All 32 biosphere reserves in the Realm;

- Agricultural activities in Gashaka-Gumti Game Reserve, Nigeria;

- Domestic livestock use and the Central Kalahari Game Reserve, Botswana;

- Traditional knowledge of natural forests in Madagascar;

- Potential for controlled utilization of wildlife in the Omo/Gambella region, Ethiopia;

- Bangweulu Swamp and floodplain, Zambia;

OBJECTIVE 3.3. TO FACILITATE PUBLIC ACCESS TO SUITABLE PARTS OF THE PROTECTED AREAS SYSTEM FOR TOURISM, RECREATION AND EDUCATIONAL USES.

\section{Activities at the National Level}

3.3.1. Examine the protected areas system and select areas suitable for development as tourist and recreation zones.

3.3.2. Develop these zones in an aesthetic manner within limits of their carrying capacity so as to promote visitors' understanding and enjoyment of nature.

3.3.3. Provide relevant educational and interpretation facilities in these zones and train locally-recruited guides.

\section{Activities at the International Level}

3.3.4. Support government agencies in their efforts to design, promote, and implement a few demonstration projects on making protected areas accessible for local tourism, including such areas as:

- Volcanoes National Park, Rwanda;

- Shimba Hills National Reserve, Kenya;

- Arusha and Mikumi National Parks, Tanzania;

- Abijatta-Shalla National Park, Ethiopia;

- "W" National Park, Niger/Benin/Burkina Faso;

- Djoudj National Park, Senegal;

- Comoé National Park, Ivory Coast

- Ste Anne Marine National Park, Seychelles 
3.3.5. Organization of training workshops in wildlife tourism development and management for tourist development corporations, national parks tourist offices, etc. (Action: World Tourism Organization, development agencies, etc.)

\section{OBJECTIVE 3.4. TO DEVELOP STRATEGIES FOR REDUCING CONFLICTS AT THE INTERFACE BETWEEN HUMAN ACTIVITIES AND PROTECTED AREAS.}

\section{Activities at the National Level}

3.4.1. Greatly increase activity in fields of conservation education, extension and human ecological research in areas adjacent to protected reserves.

3.4.2. Cooperate with management agencies to plan development and resource utilization in such areas.

3.4.3. Plan and develop buffer zones with gradients of resource use and resource protection from park to settled or exploited areas.

3.4.4. Recruit local people into the conservation agency itself, including opportunities for seasonal employment.

3.4.5. Implement programmes designed to lessen negative impacts arising from conservation, e.g. control of agricultural pests, stockraiders, diseases, etc., by direct means or barriers.

3.4.6. Develop programmes designed to show benefits to people from conservation measures, e.g. provision and regulation of water flows, excess product offtake in buffer zones, tourism, and spawning and nursery habitats.

3.4.7. Develop systematic procedures and expertise for undertaking environmental impact assessment investigations on all new developments in the areas adjacent to protected areas, as well as other areas of conservation importance.

\section{Activities at the International Level}

3.4.8. Support action by Government agencies to design, promote, and implement a few demonstration projects dealing with boundary conflict situations, including such areas as:

- National Parks in the north of Central African Republic;

- Maswa Game Reserve, Tanzania;

- Masai Mara National Reserve, Kenya;

- Kiunga Marine Reserve, Kenya; 
- Queen Elizabeth National Park, Uganda;

- Awash National Park, Ethiopia;

- Outamba-Kilimi National Park, Sierra Leone

- Makgadikgadi Pan Game Reserve, Botswana;

- Forêt du Day National Park, Djibouti;

- Bénoué National Park, Cameroon;

- Korup National Park, Cameroon;

- Virunga and Maiko National Parks, Zaire;

- Mana Pools and Zambesi Reserves, Zimbabwe and Zambia;

- Zakouma National Park, Chad.

3.4.9. Promote independent environmental impact assessments for all development projects affecting protected ecosystems (e.g. Tsetse control in the Okavango; water development schemes in the Sudd and Zambesi Valley; trans-Africa highway in southern Cameroon, mining in "W", etc.).

3.4.10. The contribution of protected areas towards controlling desertification should be brought to the attention of international and regional authorities.

3.4.11. Ensure that related activities of the World Bank are in accordance with its new Wildlands Management Policy.

GOAL 4 STRENGTHEN REGIONAL COOPERATION IN THE DEVELOPMENT OF CONSERVATION ACTIVITIES

OBJECTIVE 4.1. TO PROMOTE COOPERATION AMONG THE COUNTRIES OF THE AFROTROPICAL REALM TO ENSURE MORE EFFECTIVE MANAGEMENT AND PROTECTION OF THEIR NATURAL RESOURCES.

\section{Activities at the National Level}

4.1.1. Interchange of ideas, information and expertise in conservation among nations, at senior policy, professional and research levels.

4.1.2. Offer frequent study tour and working tour facilities to examine conservation activities within the countries of the region.

4.1.3. Interchange expert staff between national management agencies, particularly where expertise is needed to address specific problems, such as:

- Rhinoceros management in Nakuru National Park, Kenya;

- Crocodile management (expertise available from Zimbabwe and Ivory Coast on captive rearing and subsequent release);

- Marine and coastal conservation in the Seychelles; 
- Exchanges between Conservation Training Schools in Tanzania, Cameroon, Kenya and Zimbabwe;

- Elephant control and management in Zimbabwe;

- Estuarine and tidal swamp conservation issues, including linkages with deforested catchment areas in Mali and Mauritania;

- Identification and management of threatened sites rich in wild relatives of economic plants through expertise from scientists in national biological/agricultural institutes;

- Use of barriers such as electric fencing in control of nuisance wildlife;

- Wildlife utilization in the model project at Nazinga in Burkina Faso and at Lamto in the Ivory Coast;

- Turtle management across international frontiers.

4.1.4. Free exchange of data, public information and expertise regarding conservation activities.

4.1.5. Give support to international conservation agencies and conventions.

4.1.6. Ensure that permission to attend seminars, have study leave, and other means of international contact be given to qualified junior and senior-level staff.

4.1.7. Ensure that appropriate representatives are provided the necessary support from government budgets to attend major international conservation meetings, including meetings of CITES, IUCN, UNEP, and others.

4.1.8. Subscribe to both national and regional publications in the conservation field, and ensure that they are distributed to the appropriate field-level personnel.

4.1.9. Encourage conservation of ficers to contribute to newspapers, magazines, journals, and other media, thereby contributing to increasing awareness of conservation within the country and region.

\section{Activities at the International Level}

4.1.10. Provide scholarships to regional training institutes at Mweka and Garoua. (Action: Unesco, FAO, WWF, IUCN, AWF, EAWS)

4.1.11. Compile a registry of expertise from within the region to carry out advisory and consultancy assignments, facilitating exchange of ideas and building confidence in proven management techniques.

4.1.12. Support technical exchanges between countries, including training seminars, study tours, working assignments, etc., to provide the spread of good management techniques. (Action: UN system under TCDC programme) 
4.1.13. Support the establishment of institutional foci for the scientific management of wildlife and other living resources within the Afrotropical Realm, with responsibilities for training, research, convening periodic meetings, publishing realm-based conservation reports, etc. (Action: FAO, UNEP, IUCN, Unesco, CIC, and bilateral agencies)

4.1.14. Support specific requirements for training in various aspects of protected area management including:

- Special requirements of management in moist forest protected areas;

- Exotic plant and introduced animal control in protected areas;

- Wildlife capture/translocation;

- Establishment of community development and extension programmes around protected areas;

- Island and marine park management;

- Economic botany of wild crop relatives/medicinal plants in protected areas (including public awareness).

4.1.15. Sponsor seminars, workshops, etc. designed to bring professional managers in the region together on a regular basis. (Action: OAU, IUCN, Unesco, CIC, FAO) Possibilities include:

- African Regional Wildlife Conference;

- FAO Wildlife and Forestry Working Groups;

- Convene regular working sessions of IUCN's Commission on National Parks and Protected Areas;

- African Elephant and Rhino Group (SSC);

- Marine Turtle and other Species Specialist Groups (SSC).

4.1.16. Promote linkages between university departments and institutions with an applied emphasis on wildlife biology and management and expertise in the conservation education/interpretation fields. (Action: Unesco, bilateral agencies)

4.1.17. Provide materials - including books, journals, etc. - to the managers of protected areas in required languages.

\section{OBJECTIVE 4.2. TO DEVELOP AND STRENGTHEN BILATERAL/ MULTILATERAL AGREEMENTS TO CONSERVE SHARED FAUNAL OR FLORISTIC RESOURCES.}

\section{Activities at the National Level}

4.2.1. Develop, where appropriate, bilateral/multilateral treaties governing the conservation of shared or migratory natural resources. 
4.2.2. Sign and adhere to the existing international conservation conventions: World Heritage, Ramsar and CITES.

4.2.3. Designate, where appropriate, joint protected areas along common boundaries to effectively conserve shared resources, possibly using the concept of "International Peace Park" as already implemented in several parts of the world. Afrotropical areas which might be appropriate for such cooperative action include:

- Mara/Serengeti; Kenya, Tanzania;

- Mt. Elgon; Kenya, Uganda;

- Gambella/Boma; Ethiopia, Sudan;

- Gebel Elba; Egypt, Sudan;

- Mt. Nimba; Ivory Coast, Guinea, Liberia;

- Bwindi Forest; Uganda, Zaire;

- Ruwenzori/Virunga/Volcanoes; Uganda, Zaire, Rwanda;

- Mana Pools/Zambesi; Zimbabwe, Zambia;

- Boni/Lag Badana; Kenya, Somalia;

- Pendjari/Arly/"W"; Benin, Burkina Faso, Niger;

- Saloum Delta; Senegal/Gambia;

- Nyika National Parks; Malawi, Zambia;

- Niassa Game Reserve/Rovuma; Mozambique, Tanzania;

- Kruger National Park/Limpopo; South Africa, Mozambique;

- Caprivi Game Reserve/Luiana National Park/Sioma Ngwezi; Namibia, Angola, Zambia;

- Djoudj National Park/Diawling; Senegal, Mauritania;

- Niokolo Koba/Badiar National Parks; Senegal, Guinea;

- Dic Boule (proposed); Ivory Coast, Benin;

- Maluti Mountains/Drakensburg; Lesotho, Natal.

\section{Activities at the International Level}

4.2.4. Provide any necessary coordinating mechanism for promoting inter-governmental cooperation to implement bilateral or multilateral agreements to conserve shared resources, including:

- Cooperation on management of species which migrate across adjacent borders, including marine species such as turtles and dugongs;

- Management of riverine ecosystems shared by countries;

- Migratory species conventions;

- Special efforts to develop the capacity to manage living marine resources through the existing UNEP Regional Seas Programmes;

- Coordinated management of World Heritage Sites which cover two countries (Mt. Nimba, and others proposed for Serengeti, Mana Pools, Victoria Falls, Ruwenzori). 
4.2.5. Promote a programme for twinning protected areas in different countries to permit exchanges in the fields of education, planning, research and training. (Action: IUCN)

\section{GOAL 5. MONITOR THE IMPLEMENTATION OF THE ACTION STRATEGY}

\section{OBJECTIVE 5.1. TO REVIEW PROGRESS ON IMPLEMENTATION OF THE ACTION STRATEGY THROUGH CONTINUOUS MONITORING OF RELEVANT ACTIVITIES.}

\section{Activities at the National Level}

5.1.1. Promote the implementation of the Action Strategy, through wide publicity among citizen groups and related government departments.

5.1.2. Contribute to international coordination through keeping IUCN informed on actions contributing to the Action Strategy.

5.1.3. In each country, non-governmental conservation organizations to monitor implementation of the Action Strategy.

\section{Activities at the International Level}

5.1.4. Promote the implementation of the Action Strategy through project development and wide publicity in the region and internationally. (Action: IUCN)

5.1.5. Ensure that follow-up activities with FAO, Unesco and UNEP are coordinated through the Ecosystem Conservation Group mechanism.

5.1.6. Use facilities and mechanisms in IUCN's Regional Offices in Nairobi, Dakar and Harare to coordinate regional action on implementing the Action Strategy.

5.1.7. Monitor the implementation of the Action Strategy and update at future Afrotropical working sessions of CNPPA and other Commissions. (Action: IUCN) 


\section{Biogeographical Provinces of the Afrotropical Realm}

$$
\text { (After Udvardy, 1975) }
$$

1. Guinean Rainforest

2. Congo Rainforest

3. Malagasy Rainforest

4. West African Woodland/savanna

5. East African Woodland/savanna

6. Congo Woodland/savanna

7. Miombo Woodland/savanna

8. South African Woodland/savanna

9. Malagasy Woodland/savanna

10. Malagasy Thorn Forest

11. Cape Sclerophyll

12. Western Sahel

13. Eastern Sahel

14. Somalian

15. Namib

16. Kalahari

17. Karroo

18. Ethiopian Highlands

19. Guinean Highlands

20. Central African Highlands

21. East African Highlands

22. South African Highlands

23. Ascension and St. Helena Islands

24. Comores and Aldabra

25. Mascarene Islands

26. Lake Rudolf

27. Lake Ukerewe (Victoria)

28. Lake Tanganyika

29. Lake Malawi (Nyasa)

The Seychelles (apart from Aldabra) are in the Indomalayan Realm of Udvardy (1975). The Prince Edward Islands are in the Antarctic Realm. 


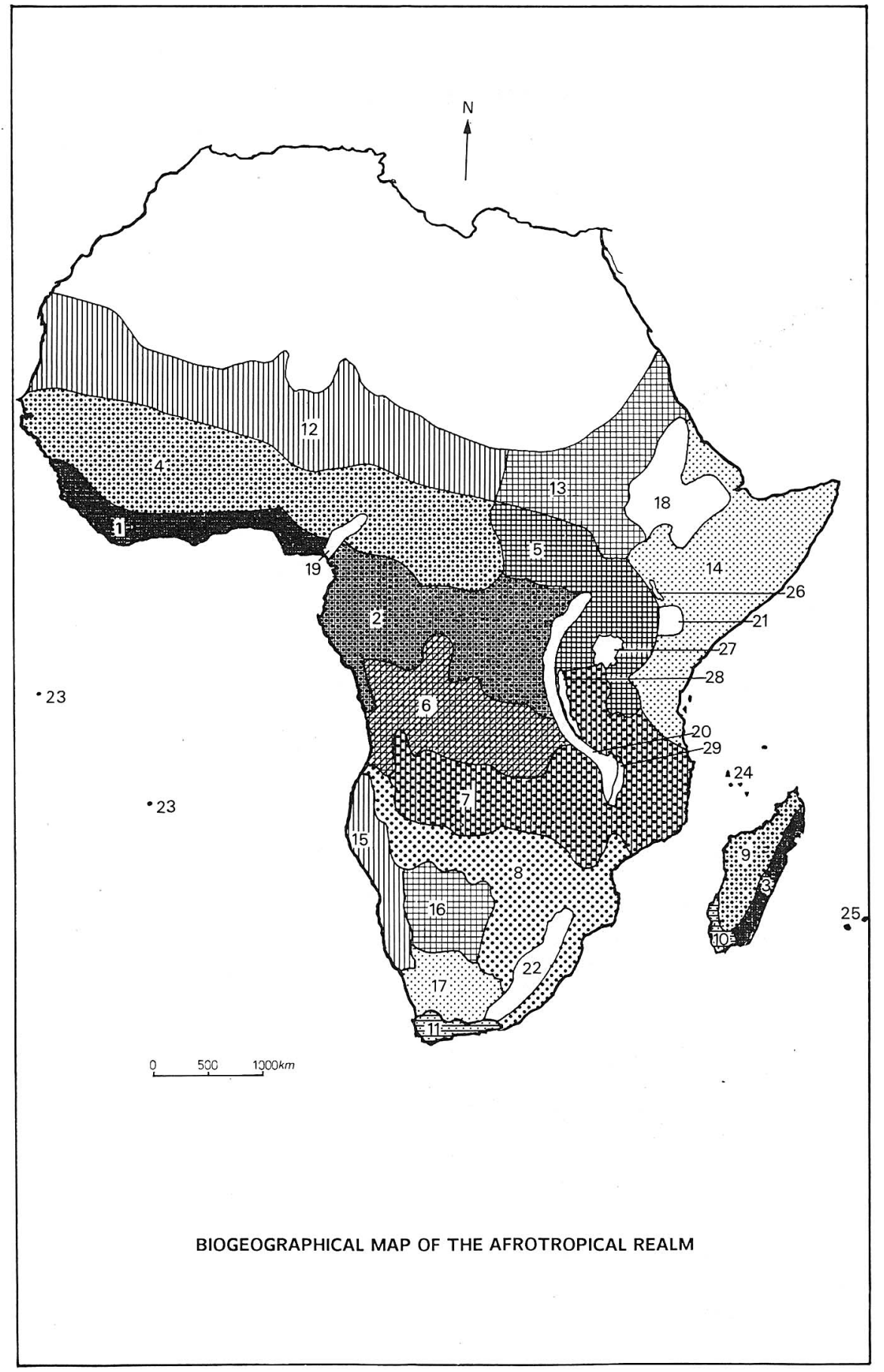




\section{PART B}

\section{AFROTROPICAL COUNTRY PRIORITIES FOR ACTION ON PROTECTED AREAS}

The main body of the Action Strategy has addressed issues and specific problem areas where attention is required. This annex provides a list of site-specific actions which have been identified as priorities for individual countries. (Listing of actions are not in order of priority).

It is recommended that after suitable refinement and consultation these lists be considered for implementation by authorities in the respective countries.

\section{ANGOLA}

1. Improve administration, management and protection of all existing reserves. At present there is a serious lack of staff, funds and resources in the existing reserves. The situation in southern Angola can only improve after resolution of the civil conflict there.

2. Establish a new reserve to protect relict patches of forest and endemic species found on Mt. Moco.

3. Establish a managed nature reserve to protect the Humbe/Bailundu Mountains in Angola, an area of plant and bird endemism and species richness.

4. Create a new reserve to protect relict patches of the Angolan escarpment forests which contain a high proportion of endemic forms (particularly at Amboim/Gabela).

5. Form a Giant Sable national park by joining Kangandala with Luando River to create a large viable ecosystem covering the main existing range of this species. The heavily populated parts of Luando River should be excluded from the park as should other areas of intensive cultivation and livestock encroachment. Include and conserve examples of major habitat types within this new park, e.g. floodplain for lechwe, riverine habitat for hippo and crocodiles, and scenic stretches of the Cuanza and Luando Rivers.

6. Extend Kisama National Park to include both banks of the Cuanzo and Longa Rivers with complete protection for all mammals and avifauna.

7. Survey remaining lowland forests in the Cabinda enclave to identify a suitable area for a reserve for the endangered lowland gorilla and chimpanzee whose forest habitat is being destroyed by logging.

8. Establish a new reserve in the Anharas do Alto of the provinces of Huambo and Benguela. 
9. The Directorate of Nature Conservation should be moved to a ministry more directly concerned with conservation, e.g. Natural Resources or Tourism.

10. Revise laws and regulations governing hunting, open and closed seasons, protected species and protected areas. In particular the giant sable should be legally protected even outside present park boundaries.

\section{BENIN}

1. Carry out in collaboration with EEC a national inventory to identify areas important for wildlife and suitable for new reserves. Some of the forest reserves in central Benin may merit upgrading to higher protection status. The Lama and Pobé forests in the south also require protection.

2. Extend Pendjari National Park from 275,500 ha to 295,000 ha by extending the park southwards. This would protect some extra species of birds and mammals, especially primates.

3. Strengthen institutional responsibility for protecting wildlife; at present parks are the responsibility of the Forestry Department.

4. The "W" and Pendjari National Parks, as part of one of the most extensive and important protected areas in West Africa, deserve continued international assistance for their management and development for tourism.

\section{BOTSWANA}

1. Extend Chobe National Park to include the Forest Reserve.

2. Investigate the potential of Lake Ngami $(6,500 \mathrm{ha})$ as a nature reserve. Lake Ngami is a very important wetland habitat in southern Africa. It is one of the few breeding sites for pelicans in southern Africa, a seasonal feeding ground for flamingoes and an important wintering site for inter-tropical and Palaearctic migrants. If it is still viable the entire lake should be designated as a wetland site under the Ramsar Convention as should parts of the Okavango Delta.

3. The following areas should receive formal conservation status as recommended by FAO (1977):

Okavango River Front
Tsodilo Hills
Aha Mountains
Kwebe Hills
Tamafupa/Jari Pan Complex
Pataletsabe Hill
Shashe Elephant Reserve
Lepakola Hills

Okavango River Front

Tsodilo Hills

Kwebe Hills

Tamafupa/Jari Pan Complex

Pataletsabe Hil

Lepakola Hills

$$
\begin{array}{r}
10,000 \text { ha } \\
9,000 \text { ha } \\
100,000 \text { ha } \\
10,000 \text { ha } \\
120,000 \text { ha } \\
6,000 \text { ha } \\
45,000 \text { ha } \\
10,000 \text { ha }
\end{array}
$$




$\begin{array}{lr}\text { Tswapong and Mabeleapodi Hills } & 20,000 \text { ha } \\ \text { Shosong Hills } & 10,000 \text { ha } \\ \text { Mokwane Hills } & 10,000 \text { ha } \\ \text { Notwane-Limpopo Area } & 1,000 \text { ha }\end{array}$

4. Protect the Tsodilo Hills and Drotsky's Caves in Western Ngamiland as national monuments of historical and cultural significance.

5. Redesignate some game reserves as nature reserves or national parks and upgrade their management.

6. Protection and management need to be improved in all reserves but especially in Gemsbok National Park (at present adequately protected only on the South African side) and Moremi Game Reserve, which are sites of international importance.

7. At present conservation in Botswana is hampered by the serious inadequacy of the nation's two major wildlife laws enacted in 1961 and 1972; the most harmful provisions are those permitting transfer of hunting licences and allowing unlicensed people to "assist" hunters. These laws require major revision.

\section{BURKINA FASO}

1. The Arly Reserve is the best site for a national park in Burkina Faso with the greatest densities of wild animals. The proposed national park could be extended by including a zone to the west to connect with the Singou Reserve. Pgou and S.E. Gobnangou should also be included in a protected buffer zone.

2. Establish a protected area $(280,000 \mathrm{ha})$ in the Komoe-Leraba area to ensure coverage of a portion of the ecosystem of south-west Burkina Faso.

3. The legal status of the Deux Bales Forest Reserve should be reviewed in light of agricultural and mining activities which are in conflict with the elephant populations there.

4. Establish the proposed Sahel (Seno-Mango) reserve with revised boundaries to include only the north-west corner of the existing Biosphere Reserve and excise all densely settled and grazed areas. Only the relatively small, untouched area of Sahel vegetation with its remaining Sahelian fauna is worth conserving.

5. Establish the proposed ornithological reserves of Beli and Mare d'Oursi.

6. Implement appropriate management activities in the buffer zones around Po

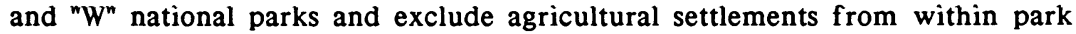
boundaries. Com \pm ensate with village development assistance. 


\section{BURUNDI}

1. Gazettement of the Ruvubu National Park and Rusizi Reserve have doubled the extent of "protected areas" within Burundi. With so much competition for land from the large and expanding human population it is unrealistic to expect further extensions of the reserve system.

2. Finalize and implement a management plan for the Kibira National Park with assistance from France and USAID.

3. Consider upgrading the legal status of the Buriri Forest Nature Reserve and implement management measures to more effectively protect the area.

4. Develop an education and extension programme to increase public awareness of the benefits of national parks and protected areas by protecting watersheds and as reservoirs of natural resources.

\section{CAMEROON}

1. Some new protected areas should be established in the Afromontane forests which are currently under-represented in the protected area system. It is not feasible to protect the entire Mt. Cameroon area but it would be useful to increase the protection status of the Bambuka Forest Reserve and also to establish a protected area to the south of Mt. Cameroon, including the peak of Little Mt. Cameroon, Etinde.

2. Other montane areas of interest are Mt. Kupe and Mt. Oku in the Bamenda highlands. The Mt. Oku forests (which have several endemic bird species) are included in the proposed Lake Oku Reserve. The Lake Balambi Mbo area near Kumbe is also of interest (the lake itself has 12 endemic species of fish). In addition the value of Faro National Park would be greatly enhanced if it could be extended higher into the mountains.

3. Implement the management plan for the new Korup National Park with the financial assistance of WWF and ODA.

4. The existing Pangar-Djerem Game Reserve has been whittled away by agricultural encroachment and is seriously threatened by poaching, made easy by railway access through the reserve. The proposal to establish an alternative national park in the adjacent Mbam-et-Djerem area is recommended.

5. A useful addition to the protected area system would be part of the swamp forests of the Nyong/Long River near the town Abang Mbang; this is a unique and currently unprotected vegetation type in the country. 
6. An assessment should be made of the status of flora and fauna of the Takamanda Forest Reserve and protection and management improved to conserve its wildlife. This area is important as the main refuge of the isolated northern gorilla population which may be a distinct race, as well as being important for leopard, elephants and other valuable wildlife.

7. Areas for possible marine parks should be surveyed. One possible site is the Rocher du Loup area of the Campo Reserve.

8. There is a need to conduct environmental impact assessments (EIA) and to establish better inter-ministerial coordination in planning major developments in the vicinity of protected areas. The barrage on the Keleo River, for instance, has reduced floodwater flow onto the grasslands of the Waza National Park with serious effects on both vegetation and wildlife. The impact of the new trans-Africa highway next to the Dja forest also needs an EIA.

9. The conservation importance of the various forest reserves in the country should be assessed and taken into account by the Ministry of Agriculture when planning their exploitation and future use. Some coordination between the Ministries of Agriculture, Tourism and Higher Education will be needed for such assessment.

10. The mangrove resources of the country are not yet seriously threatened but should be constantly monitored, particularly in the Bakassi area.

11. Increase efforts at management of the lowland forest parks and reserves in the southern part of the country which harbour exceptional biological diversity. Examples are Dja, Campo and Douala-Edea.

\section{CENTRAL AFRICAN REPUBLIC}

1. Select an area for a national park in the dense forest zone of the south-west to protect forest animals such as gorilla, chimp, bongo, buffalo and elephant. Such an area could be developed for tourism as a contrast to the northern plains and is now being heavily poached.

2. Establish the proposed Zanga (Bongos) reserve.

3. Wildlife conservation and development is currently concentrated in two parks: Bamingui-Bangoran and Manovo-Gounda-Saint Floris. Both parks need better protection with increased numbers of staff, transport and equipment, and continued support from the EEC.

4. There should be no attempt to declassify part or all of the Bamingui-Bangoran area. It should retain its present status as national park and reserves. The area should be proposed as a Man and the Biosphere Reserve. 


\section{CHAD}

1. Improve levels of protection and management in all protected areas by increasing staffing levels, budgets and equipment. Special attention should be paid to anti-poaching activities in coordination with neighbouring countries.

2. Rehabilitate the Zakouma National Park and the Ouadi Rime/Achime Reserves. Both have been adversely affected by military activities and the latter is especially important for oryx and addax.

3. Consider nominating Lake Fikri (160,000 ha) as a biosphere reserve and Ramsar site for its important wetlands.

4. Establish a reserve in the Aouk area (740,000 ha) in southern Chad which would include the seasonal migration route of elephants.

5. Establish the Goz-Beida National Park (300,000 ha) as well as faunal reserves at Beinamar (76,500 ha) and Larmanaye $(88,200 \mathrm{ha})$ as proposed by the local resident to protect several rare species.

\section{COMOROS}

1. Urgent measures should be taken to protect remaining areas of rainforest both to protect watersheds and wildlife; forest clearing should certainly be prohibited above $800 \mathrm{~m}$ in the central massif and above $200 \mathrm{~m}$ on Mayotte.

2. The only conservation area of any size in the islands is that proposed to protect the volcano of Karthala on Grande Comore; the Government should be encouraged to go ahead with gazettement of this forested mountain, an important habitat for several threatened bird species.

3. Marine and coastal habitats are also in need of protection. A special reserve for the coelacanth should be included as well as a turtle nesting reserve at Moheli.

\section{CONGO}

1. Implement on-the-ground management in the Odzala National Park (humid forest) and in the reserves of Conkouati, Lefini, Mont Fouar, Tsoulou and Loudima.

2. Increase the total area protected within the country's reserve system. FAO have made extensive forest surveys in the Congo. Key areas of biological richness and interest including: Lac Tele (humid forest), Souanke (humid forest), Petite Bangou (dry forest), Grand Bangou (semi-humid forest), Intsini and Manières (mixed forest/savanna). 
3. Increase levels of trained staff, funds and equipment for protected areas. Present levels are totally inadequate - in 1982 there were only 9 guards with one motorboat to protect the entire protected area system while a 1986 survey indicated that $\mathbf{4 8 6}$ guards were required.

4. Extend Conkouati Reserve to the coastal zone to include marine features.

\section{DJIBOUTI}

1. Extend Day National Park to include as much as possible of the remaining relict of the Goda Mountain Forest (in total 42,000 ha). The Forêt du Day is a relict juniper forest in the Goda Mountains, and the only known site for Francolinus ochropectus. Other measures required include prevention of forest destruction due to fire, browse for cattle and during firewood and honey collection. Overgrazing and trampling by stock are other serious problems and livestock should be excluded from the Park.

2. Protect remaining areas of coastal mangrove and of fshore seabird colonies on Sept Frères.

3. Encourage cooperative conservation and tourism programmes between Djibouti and Ethiopia in the lakes region on their common border in the Danakil depression.

\section{EQUATORIAL GUINEA}

1. Establish the reserve system of mainland Equatorial Guinea and the islands of Bioko and Annobon.

2. Establish Mt. Alen National Park $(80,000$ ha), an area important for lowland gorillas, elephants and leopards.

3. Establish a rainforest reserve of 30,000 ha in the Mitra Mountains, encompassing the peaks of Atom, Mabumu-Wom, Bekuo, Mitong, Mitono.

4. Establish a reserve of 40,000 ha in the Altos de Nsok area.

5. Establish reserves to protect the Rio Muni estuary and coastal waters ( $70,000 \mathrm{ha})$, only known habitat for manatees in Equatorial Guinea, and the Campo estuary $(20,000 \mathrm{ha})$, habitat for birds, crododiles and hippopotamus.

6. At present there are no reserves on Bioko (Fernando Po). Although much of the island vegetation has been destroyed to make way for coffee plantations. 
The remaining montane forest should be protected to conserve its unique montane flora which shows strong affinities with that of Mt. Cameroon. Specifically recommended are:

- the establishment of a reserve of 60,000 ha in the south-west of the island to include offshore coastal waters and give protection to island endemics and marine fauna, including Green Turtles and cetaceans;

- the establishment of a reserve of 35,000 ha to protect the montane and lowland forests on Saint Isobel/Malabo.

7. Declare the island of Annobon a conservation area, including the fringing coastal waters which support important colonies of seabirds, turtles and cetaceans.

\section{ETHIOPIA}

1. Gazette the already established Bale Mountains National Park, Ethiopia, created to conserve the largest area of Afro-alpine habitat in Africa and to protect the water catchments of three of Ethiopia's main rivers;

2. Except for the Awash and Simien National Parks other conservation areas are not gazetted although some have been developed; these reserves should be gazetted as soon as possible.

3. It is several years since a marine national park was first proposed in the Dahlak islands, yet no detailed study of the area has been carried out. These islands are an important breeding site for seabirds, turtles and dugongs. The islands and surrounding seas should be assessed for development as a marine park.

4. Establish a wildlife sanctuary at Yavello near the Ethiopia/Kenya border, an area rich in wildlife (e.g. three threatened endemic bird species).

5. The following lakes which are important habitat for flamingoes should be given some protection: Lakes Zwai, Langano, Awasa, Abaya and Chamo. Lakes Abijatta and Shalla are already protected within the Abijatta-Shalla (Rift Valley Lakes) National Park.

6. Protect those sandy beaches which are important for turtle nesting.

7. Gambella National Park, an area of tropical forests, has one of the richest wildlife concentrations in Ethiopia. The area is threatened by adjacent agricultural developments and protection of the park is a top priority.

8. Very little of the important montane forests in Illubabor, Kaffu and Bale provinces are protected or under any form of management. Recent immigration into this area gives cause for concern for better protection of these forest remnants. 


\section{GABON}

1. Implement a programme to effect management of the existing protected area system including preparation of management plans, revisions to legislation, training of rangers and provision of basic infrastructure.

2. Additional areas in need of protection include: primary forests of the proposed Minkebe area, and savanna woodlands near Franceville, home to the last lions in the country.

3. Extend the Wonga-Wongue Reserve to include some swamp forest habitat.

\section{GAMBIA}

1. Continue to cooperate with Senegal in efforts to protect resources of the Delta du Saloum, a valuable mangrove and an important wetland for breeding waterbirds.

\section{GHANA}

1. Improve protection of the Bia National Park and upgrade the protection, management and status of some of the forest reserves important for protection flora, fauna and water catchments.

2. Identify an area of coastal mangrove for protected area status as part of a general review of mangrove forest management.

\section{GUINEA}

1. Establish the Massif du Ziama as a nature reserve, with properly defined boundaries. It has been identified as an important plant site and the Fouta Djalon has critical watershed values.

2. Undertake a resource inventory of the newly-created Badiar National Park which complements the Niokolo-Koba National Park in Senegal.

3. Carry out a wetland inventory and establish priority areas for protection.

4. To focus special attention on cooperating with Ivory Coast and Liberia in protecting the Mt. Nimba World Heritage Site, especially in light of a World Bank financed mining project in the area. 


\section{GUINEA BISSAU}

1. No protected areas have yet been established. A survey based on the forest inventory prepared by RFA is needed to assess potential with attention given to:

- an area of the remaining coastal and estuarine mangroves; this vegetation is already much reduced and manatee populations still remain;

- areas of the coastal wetlands, which are the most important wintering grounds in West Africa (after Banc d'Arguin) for Palaearctic waders;

- forest patches which have rich bird faunas, elephants and chimpanzees (possible sites are Olon, Cufada, Cantanhez and Boe);

- the offshore islands of the Bijagos archipelago are reported to be interesting for their birdlife and mammal species (including marine hippos);

- determining the potential for establishment of national parks at Cantanhez, Boe, and Lagoa de Cufada.

2. A national nature conservation training seminar should be held to review and stimulate the role of protected areas in the country.

\section{IVORY COAST}

1. Identify and give better protection to forest reserves important for biological diversity as defined in the third forestry plan.

2. Implement the existing management plans for the protected areas with priority given to Taï, Marahoué and Comoé National Parks.

3. Develop selected parks for wildlife tourism; Azagny and Comoé are especially suitable for tourism and already have some visitor facilities.

4. Taï has additional potential as a seed source for reafforestation programmes with a centre established for seed collection and propagation.

\section{KENYA}

1. Give better protection to relict patches of forest which constitute the last known examples of formerly more extensive types - in particular Kakamega forest, Arabuko-Sokoke forest and the coastal Kenya forests. Part of Kakamega is a national park (97 sq $\mathrm{km}$ ) and the other forests are designated as forest reserves, but the protection so afforded is inadequate for their biological importance. 
2. Immediate protection of all montane floristic types should be ensured by the declaration of nature reserves of adequate area in all forest reserves, e.g. Mau and Cherangani forests, Mount Elgon, Taita Hills.

3. Establish nature reserves to protect the relict humid forests of South and North Nandi; at present these are forest reserves subject to timber extraction.

4. All surviving coastal forest in Kenya should be totally protected; upgrade the forest reserves of Witu and Arabuko-Sokoke to nature reserves and stop timber exploitation.

5. Adopt protection measures for the Lorian and Lotikiri swamps.

6. Areas for protection should be identified in the Chalbi and Koroli deserts. Chalbi is an old lake bed and now a salt pan subject to occasional flooding. Koroli is a sand desert showing signs of recent degradation but sub-desert scrub might recover with adequate protection.

7. Immediate protection should be given to the estuaries, mangroves, bays and sea grass beds of the Lamu/Ras Tenewi area which are not included in any reserve and for which a feasibility study has been prepared.

8. Lake Victoria is one of the richest lakes in the world in terms of fish diversity and endemism, yet has no protection. Introductions of Nile perch into Lake Victoria have already had serious ecological consequences as well as reducing local fish catches. Some protective mechanisms are required in cooperation with Tanzania and Uganda.

9. Improve protection of Boni National Reserve, a particularly good example of the forest/savanna mosaic on the north coast; though protected as a game reserve it is threatened by felling for charcoal.

10. Extend Mt. Kenya National Park to include more natural forests that have significant wildlife and watershed values.

\section{LESOTHO}

1. Upgrade legal status and implement zoning plan for the Sehlabathebe National Park.

2. Establish the proposed reserves of Qeme Plateau, Quthing Valley and Makhaleng Valley.

3. Establish a protected area in the Oxbow/Drakensberg area to protect watershed and other values related to the Lesotho Highland Water Scheme. 


\section{LIBERIA}

1. Gazette the proposed Lofa-Manu National Park and four proposed reserves at Cape Mount Forest, Cavally Forest, Mt. Nimba and Wonegizi Mountain.

2. Lofa-Manu along with the neighbouring Gola Forest Reserves in Sierra Leone should be managed as an integrated unit with a core zone surrounded by sustained-yield timber concessions, a hunting zone and settlement area.

3. Improve the protection and management of eight national forests to better protect their plants and wildlife from forest destruction. Establish nature reserves of viable size within these national forests: Krahn Bassa (514,000 ha), Grebo (251,000 ha), Gola (207,000 ha), Kpelle (174,800 ha), North Lorma (100,000 ha), Gbe (61,000 ha), Gio (33,000 ha), and East Nimba (29,000 ha).

4. Implement the management plan for Sapo and its environs, as approved by Government.

5. Establish contacts with neighbouring countries to manage frontier reserves such as Lofa-Mano, Mt. Nimba, Wonegizi and Cavally.

\section{MADAGASCAR}

1. Secure the existing system of reserves by implementing a management regime to effect on-the-ground action.

2. Identify large undisturbed tracts of eastern lowland rainforest and establish one or more new reserves, each of at least 50,000 ha. Possible areas include the Mahakira plateau, the forests west of Maroantsera and Antongil Bay, and the Sihanaka Forest (especially important for threatened avifauna).

3. Re-establish a reserve on the Masoala peninsula, of at least 30,000 ha, to replace the area degazetted in 1964.

4. Extend the reserve of Perinet-Analamozaotra from its present size of 810 ha, which is too small to remain viable, to at least 10,000 ha to include more of the adjacent species-rich forests to the north.

5. There is an urgent need to establish a reserve in the region of Lac Aloatra, if the habitat is still worth protecting. Watershed values of the Zahamena forests are high and need better protection.

6. Surveys should be carried out to determine if there is an area of remaining lowland rainforest suitable for a reserve in the Sambirano domain.

7. Survey the mangroves of the west coast to identify an extensive area of relatively undisturbed mangrove suitable for a reserve. Possible sites include the estuaries of the Mangoky, Tsiribihana and Betsibcka Rivers, Cap Saint-Andre, the Antsohiby area and the coast west of Ambodibonara. 
8. Create a new reserve or national park to include Lac Ihotry and a substantial area of Didiereaceae bush and endemic avifauna.

9. Extend R.N.I.7. Ankarafantsika to include Lake Ampijoara and the hills to the north of the lake.

10. Revise the boundaries of "Parcelle 2" of R.N.I.11 Andohahela to excise cultivated areas from the reserve in exchange for equal amounts of undisturbed forest. Extend "Parcelle 2" westwards to include extensive tracts of spiny forest.

11. Extend R.N.I.9 Tsingy de Bemaraha to include a parcel in the west covering the region between Lakes Masamba and Bemamba. Tsingy de Bemaraha is an area of spectacular limestone scenery with interesting flora and fauna.

12. Prepare to follow-up on coral reef surveys now in process on the west and north-east coasts with appropriate conservation measures. Establish the proposed marine parks at Grand Récif, Toliara and Nosy Bé.

13. Improve protection, management and staffing levels at all reserves; this will require a manifold increase in budgets. Boundaries of all reserves should be marked clearly, perhaps with firebreaks which would also afford protection against the spread of fire from adjacent agricultural lands.

\section{MALAWI}

1. Extend Mt. Mulanje Forest Reserve and upgrade to a full reserve of Category IV status. Mt. Mulanje is the highest mountain in the region with several endemic plant species and interesting altimontane vegetation not protected elsewhere in the Malawi parks system.

2. Other isolated mountains with particularly distinct biota include the Thyolo, Sochi, Malawi, Lilonde and Nchisi Mountains; at least part of these montane systems are protected within existing forest reserves but these are subject to illegal encroachment and disturbance. These important forest reserves should be extended and their management improved to give thom better protection.

3. Although montane evergreen forest is already fairly well represented in the protected area system, top priority should be given to extending coverage of this biome as these forests contain large numbers of rare and endangered species and plants and animals with high levels of endemism. Priority forests are Chikala, Malawi, Mulanje, Mzuma, Nkhwadzi, Sochi and Thyolo.

4. Very little of the actual waterbody of Lake Malawi is protected although this is biologically the richest lake in the world with an amazing diversity of fish species (cichlids) and very high endemism. The Lake Malawi National Park boundaries should be further extended to include more of the lake's waters within the protected area. 
1. Examine the feasibility of the proposed national park in the Bafing Makana region on the Guinea border. This area includes a relict large mammal fauna, chimpanzees, elephants, giant eland and duikers. The park would mitigate losses from the Manantali dam.

2. Establish a network of protected areas in the Niger floodplain at Lac Debo, Lac Oro and Seri. This is the largest floodplain in West Africa and an important habitat for manatees, warthogs and a wide range of migratory birds.

3. Establish reserves to protect remaining species-rich forests near Sikasso.

4. Control human settlements within reserves or establish enclaves to exclude them from park lands. Discourage grazing of cattle and livestock within reserves, even in times of drought. This puts added pressure on wildlife populations when they too are stressed.

5. At present the Gourma Elephant Reserve does not give adequate protection to Mali's elephants. The existing Elephant Reserve should be redefined as a multiple use area covering the majority of the Gourma elephant range and, within this, one or more sanctuaries be established in critical habitats.

6. Consolidate the proposal for the "Réserve des Girafes" (Ansongo-Menaka), an area of Sahelian fauna (giraffe, ostrich, three species of gazelle) now threatened by poaching and encroachment by livestock.

7. Protect migration routes and habitats of the last herds of oryx and addax which migrate between Mali and Mauritania.

\section{MAURITANIA}

1. Establish the proposed Réserve du Diawling with a minimum size of at least 5000 ha in the Senegal delta adjacent to Djoudj National Park in Senegal to protect a greater portion of these important wetlands.

2. The Plateau d'El Aguer has a residual Sahelian fauna and requires more intensive management.

3. Improve protection and management of Banc d'Arguin National Park, increase the guard force, and implement the new management plan for the park. Fully incorporate Cap Blanc into Banc d'Arguin to protect adequately what is possibly the world's only viable population of monk seals Monachus monachus. 


\section{MAURITIUS}

1. Establish marine nature reserves at Baie de l'Arsenal, Blue Bay, Gabriel Reef and Serpent Island to protect coral reef and seabird nesting sites.

2. Intensify management efforts in the Macchabee/Bel Ombre Nature Reserve to better protect the endemic birds and plants and prevent further habitat degradation.

3. Consider protection measures for certain woodland sites on Rodrigues and on Agalega.

\section{MOZAMBIQUE}

1. Standards of protection and management are minimal in all of Mozambique's gazetted reserves and protected areas. Improvement will require substantial inputs of funds to increase levels of trained staff, budgets, equipment and other resources. Problems of settlement and cultivation within reserves and illegal grazing of cattle will have to be resolved. None of these problems can be tackled until the country's security problems improve.

2. Consider extending Gorongosa National Park to include Mt. Gorongosa and the Marromeu coastal wetlands.

3. Extend Niassa Game Reserve to include the very important Lugenda valley.

4. Establish marine reserves at Quirimba Island, Primeira and Segundo and Nacala-Mossuril to protect coral reefs, seabird colonies, seagrass beds and turtle nesting beaches. Assess potential of the Zambesi delta for a protected area for mangroves and birds.

5. Review the legal status and land use patterns in the Bazaruto National Park to determine its most appropriate management category.

6. Assess the level of endemism of the Chimanimani Mountains in Manica Province on the border with Zimbabwe and the feasibility for protection.

\section{NAMIBIA}

1. Improve protection and management of Caprivi Game Reserve as soon as this is feasible. At present this area is classified as a military "operational zone". Unfortunately the relatively good conservation situation in Namibia is threatened by mounting levels of guerilla warfare. 


\section{NIGER}

1. Support gazettement and development of the proposed Aïr and Ténéré National Nature Reserve, the last stronghold of Sahelo-Saharan wildlife in Niger.

2. Other Sahelian zone reserve proposals at Gadabédji and Termit should receive attention in land use planning for the region.

3. Improve protection and management of all reserves by increasing the numbers of trained staff, funding, transport and equipment. Take measures to reduce agricultural encroachment, hunting and grazing by domestic livestock within reserve boundaries.

4. Promote cooperative management of "W" National Park with neighbouring countries to strengthen management of the Park and its buffer zones.

\section{NIGERIA}

1. The southern rainforests of the country are biologically rich and a survey is required to determine their conservation status. The forests south of the Cross River area adjacent to Cameroon's Takamanda Forest Reserve and Korup National Park are of special interest. The Forest Department should be encouraged to give better protection to wildlife habitat found in those reserves.

2. Establish multiple use protected reserves in the Nadgia floodplain of Kano and Borno States.

3. Protection and management in Nigerian reserves is generally poor. Improvement will require increased levels of trained manpower, funds, equipment and other resources. Problems include expansion of enclaves within reserves (Gashaki-Gumti Game Reserve) and poaching, unauthorized fires and livestock grazing (Lake Kainji National Park). The management plans recently prepared for these two areas should be implemented.

\section{REUNION}

1. There is great potential for protecting a substantial area of mountain forest which would save a large number of endemic plant species. The Réunion forests are identified as an important plant site by the Threatened Plants Unit of IUCN. Priority should be given to establishing nature reserves on Hauts de St. Philippe, Mazerin and Bebour.

2. An improved marine protected area system is urgently required. 


\section{RWANDA}

1. Include the Nyungwe/Rugege Forest Reserve of 90,000 ha in the protected area system. This is a very important area for several species groups.

2. Improve protection and management in Akagera National Park and the Mutara and Nyungwe Reserves. Increase anti-poaching activities in Volcanoes National Park.

3. There should be no further areas excised from the existing reserve system. The Volcanoes National Park has already been reduced to the point where it is questionable if it is viable.

\section{SAO TOME and PRINCIPE}

1. Reserves need to be established in the remaining lowland rainforests on Sao Tome primarily to protect rare bird species. Montane forests should also be protected for their watershed values and unique biota particularly in the south-west of the island.

2. Hawksbill and Green Turtle nesting areas also need protection.

\section{SENEGAL}

1. Increase staffing levels and improve protection and management of the faunal reserves of Ferlo Nord and Ferlo Sud as part of a rural development plan for the area. Both areas have lost much of their conservation value over the past several years.

2. Strengthen cooperation with Guinea to stop cross-frontier poaching of elephants in the Niokolo-Koba and Badiar National Parks.

3. Continued cooperation with Mauritania for effective protection and management of the Diawling-Djoudj wetland areas and with Gambia for the Delta du Saloum reserves.

4. Establish a reserve at Kedoujou/Dendo Felo to protect chimpanzees living outside Niokolo-Koba.

\section{SEYCHELLES}

1. Creation of the eight marine reserves proposed under the UNEP Regional Seas Programme should receive urgent attention.

2. Support for the Aldabra World Heritage site should include prospects for economic returns from nature-oriented tourism. 


\section{SIERRA LEONE}

1. All three of the Gola Forest Reserves should be given full conservation status. At least 44 species of mammals are found in Gola. Forest concessions to SILETI in Gola should be revoked and the type and intensity of logging limited in Gola North. Gola West and East should be designated as a national park; Gola North should become a game reserve. Part of Gola East should be designated a strict nature reserve to protect unique flora and fauna and prevent siltation of the Mano River Reservoir. By protection of permanent forest corridors, Gola could be linked to Lofa Mano Reserve in Liberia across the Mano River; this would allow animal movement and genetic exchange.

2. The Kangari Hills, Kuru Hills, Tingi Hills, Loma Mountains and Tama Forest Reserves should all be given full conservation status to safeguard relict forest fauna including forest elephants. Loma Mountains should be declared a national park and the other areas become game reserves.

3. The Western Area Forest Reserve should be given full conservation status and developed as a national park. This area is only of modest conservation importance but lies conveniently close to the country's capital so would make an excellent national park.

4. Establish national parks to protect important freshwater areas such as Lakes Sonfon, Mape and Mabesi and their surroundings.

5. Establish a protected area to protect the mangrove in the Sherbro River delta.

6. Establish reserves to protect coastal mangroves. Possible sites include Yelibuya Island; Bumpe, Yawri Bay; Sewa/Waanje, Bonthe; Kpaka, and Pujehun.

7. Establish Outamba Kilimi as a national park with full legal protection. Outamba-Kilimi, an area of savanna woodlands has some fine gamelands, but the vegetation is rather degraded and mostly secondary. Chimpanzees occur in this area.

8. Give official Government protection and legal status to the proposed Mamunta-Mayoso Swamp Nature Reserve (16,000 ha).

9. Establish game reserves to protect the "Lophira grasslands" of Port Loko and Bo.

10. At present few reserves have any conservation status other than forest reserves with no-hunting zones. All the reserves proposed above deserve conservation status but immediate protection in order of their conservation importance should be given to:

- part of the Gola Forest Reserves;

- Sherbro delta and other mangrove areas; 
- Outamba-Kilimi;

- Western Area;

- Mamunta Swamp.

\section{SOMALIA}

1. Create several small parks in the trans-Juba region before all land is given over to agriculture.

2. Establish the mountain area of the Daalo Forest as a national park. The area has good Juniperus forest, leopards in the mountains and is home to the rare Warsangali linnet. Extend the boundaries of this forest reserve to the east to protect a population of wild ass and Beira gazelle.

3. Establish a national park in Las Anod to protect wild ass, oryx and gazelle which at present suffer from competition from grazing domestic wildlife. The Taleh area should be established as a wildlife reserve. El Chebet should also be protected; this is a permanent grazing area but is rich in prehistoric sites and the rare creeping palm also occurs here.

4. Protect Far Wamo as a wildlife reserve. This area is important for elephants, giraffes and rhinos and provides a dry season water supply.

5. Establish the proposed Gaan Libaax national park but choose better boundaries and declare the adjacent Waggar Mountains a forest reserve.

6. A partial reserve was established at Zeila in colonial times. This should be re-established to include the Libaax Xeeleh Mountains (at present a forest reserve) rich in montane fauna and flora, and the area of Zeila and offshore islands.

7. Establish Lack Dere as a national park and wildlife reserve. This area includes Hunter's and Grant's gazelles. It has potential for tourism development.

8. Establish Jowhar Warshek as a national park. This includes the area designated as Mogadishu Game Reserve. Make realistic boundaries to the park limiting it to a strip of swamp, a tract of riverine formation and dunes and coastal plain. The swamp is rich in birds, hippos and crocodiles. The coastal plains support Soemmerring's and Speke's gazelle, kudu and gerenuk.

9. Establish a marine park to protect coral reefs, turtle nesting sites and dugong. Possibilities occur in the Bajuni archipelago and along the coast adjacent to the Lag Badana National Park.

10. Establish Hobyo Game Reserve to protect dibatag, oryx, Soemmerring's and Speke's gazelles.

11. Establish Harqan-Dalandoole as a national park or wildlife reserve. 
12. Establish a wildlife reserve at Haradere-Awale Rugno, a key area for dibatag and Soemmerring's gazelle.

13. Establish a wildlife reserve or national park to protect Gezira lagoon, important for its bird fauna and rare plants.

14. Establish a wildlife reserve in the Boja swamps, which has elephant and buffalo populations.

15. Establish enclaves to excise villages from national parks and reserves, e.g. at Lag Badana.

\section{SOUTH AFRICA}

1. Extend the protected area system to include adequate areas of two very distinct, rich habitats virtually unique to South Africa. Identify areas of lowland fynbos and succulent Karoo suitable for gazettement as protected areas.

2. Provide better protection for the Ngoye Forests in Natal/Kwazulu which are important for birds.

\section{SUDAN}

1. Sudan is in great need of its remaining forests and all areas should be carefully conserved and utilized. The Imatong Mountains in the south-east are the only area of montane forest but are currently the site of tea and forest development. Top priority should be given to establishing a conservation area $(20,000 \mathrm{ha})$ in these mountains to protect the unique flora and fauna.

2. As yet there are no conservation areas in the desert zone of Sudan which makes up $35 \%$ of the country, an area important for at least eight species of threatened ungulates. Similarly there are no reserves in the arid zone, also important gazelle habitat and home to dry-area carnivores such as fennec and sand foxes. Priority should be given to establishing a reserve in the Red Sea Hills, an important area for Nubian ibex, gazelles and other mammals which have no protection at present. The value of this conservation area would be further enhanced if it could be linked with a Marine Conservation Area.

3. Priority should be given to establishing a reserve to protect Jebel Marra, an isolated mountain block with a unique flora and fauna.

4. All proposed conservation areas should be gazetted as soon as possible. These include Boma and Lantoto National Parks and the game reserves of Boro, Meshra and Badingilo. 
5. The Sudd Swamps are an ancient swamp area of major importance. Their conservation and wise management are a conservation priority. The Sudd is already protected by the Zeraf and Fanyikang Game Reserves, but management and protection of these reserves needs to be improved. The effects of major developments in the area (oil exploration and the Jonglei Canal) will have considerable impact in the near future and need to be monitored.

6. Sudan has only a tiny edge of the great central Africa rainforest, represented in Bangangai Reserve. Although this habitat is well-represented in other countries of the region, Bangangai and other small sites such as Bire Kpatuos are of national importance and measures should be taken to improve protection and management of these rainforest habitats.

7. An effective management regime needs to be implemented at the Sanageb reef area and the area needs to be legally gazetted.

8. To prevent further losses of species diversity and abundance, the management programme for Dinder National Park as prepared by FAO needs immediate implementation.

\section{SWAZILAND}

1. Establish a protected area in the Mahamba Gorge to preserve the Bald Ibis breeding colony.

2. Investigate protected area potential for the Makhonjwa Hills (moist forests); Mnyame Gorge (cycads); and Ngwempisi Gorge (scenery).

3. Review boundaries of the Mlawula Nature Reserve to consider the Androstachys forests on the north edge of the Mbuluzi River and oribi habitat west of Mhlumeni.

4. Consider creation of a reserve in the Libombos Mountains in cooperation with Mozambique.

\section{TANZANIA}

1. Top priority should be given to establishing conservation areas in the Usambara, Uluguru, Uzungwa, Rungwe and Mahale Mountains. At present these areas contain some forest reserves; the Mahale Mountains has been gazetted but no management regime has been established.

2. Few extensive swamps in eastern Africa are included in parks and reserves. In Tanzania the following swamp areas still require protection: Wembere, Kilombero, Bahi and Kagera swamps. Management of the Uwanda Reserve and the Moyowosi Game Reserve, which protects part of the Malagarsi swamp, needs to be reinforced. 
3. The flood plains of Buhoro, Kilombero, Wembere, Malagarasi and Lake Rukwa are unprotected with the result that their wild mammal populations are subject to uncontrolled hunting.

4. Itigi thicket is a restricted biome in central Tanzania, though extensive and well-protected in other parts of the Zambesian region, and formerly an important habitat for rhino. At present it has no conservation status and is felled for agriculture. This area should be partly protected by the declaration of a game or forest reserve.

5. Although several alkaline lakes are fully or partly protected, Lake Natron is unprotected, even though it is the only breeding place for lesser flamingoes and many of the greater flamingoes in eastern Africa. The following lakes should be protected as important flamingo habitat: Lakes Natron, Eyasi, Balangida, Balangida Lelu.

6. The open water of most freshwater lakes in eastern Africa (except for very small ones) is excluded from national parks and protected areas although adjacent land areas may have park status. Lakes Tanganyika and Victoria are two of the richest lakes in the world in terms of fish diversity and endemism yet none of their open water is protected. Extend the park boundaries of Mahale National Park and Gombe Stream National Park to one kilometer offshore to protect part of Lake Tanganyika.

7. No areas of mangrove are protected in Tanzania. Immediate action should be taken to establish a reserve in the Rufiji Delta, the most extensive area of mangrove on the Tanzanian coast. This area could be proposed as a national park or part of a marine park.

8. Although there are extensive coastal reefs along the entire eastern coast of Africa from Egypt to Mozambique, few are protected in national parks or reserves. There is an urgent need to establish a marine park to protect the coral reefs off the Tanzanian coast. There is good coral on Mafia Island which together with the Rufiji Delta could form important marine parks.

9. Establish conservation areas to protect areas of saltbush thicket (Suaeda) on the margins of Lake Manka and the Ruvu valley, and fringing the coastal salt pans.

10. Establish a reserve to protect riverine and swamp forest along the lower Kagera River between Uganda and Tanzania, important habitat for blue duiker and black mangabey.

11. Coastal forest is inadequately protected in Tanzania. Prime sites are the Pugu Hills near Dar es Salaam, the Kichi Hills south of Rufiji, and the Rondo Plateau in the south-east.

12. The islands of Fungu Kisimkasi and Latham off the Tanzanian coast are important for seabirds and turtles and should be gazetted as game reserves. 
13. Improve protection of Selous Game Reserve which has suffered a drastic reduction in numbers of elephants and rhinos due to heavy poaching.

14. Establish a border park in the Rovuma area in cooperation with Mozambique to protect the elephant population there.

15. Although there are major wildlife values on the islands of Zanzibar and Pemba, no protected areas exist. Jozani Forest and adjacent coral rag thickets and mangroves on Zanzibar require gazettement to protect endemic colobus and small bovid communities. Part of Ngezi Forest on Pemba should be given full protection as one of the major wet coastal forests in east Africa.

\section{TOGO}

1. Gazette the proposed Mandouri Reserve.

2. Implement a management plan for the Keran National Park and the adjacent Hunting Reserve.

\section{UGANDA}

1. High priority should be given to establishing a national park in the Ruwenzori Mountains. Most of the Ruwenzori Mountains lie within Uganda; the adjacent area in Zaire is already protected within the Virunga National Park.

2. Several other areas of remaining forest with high species diversity and endemism are presently inadequately protected as forest reserves but should be gazetted as full reserves:

- Bwindi (Impenetrable) Forest is one of the largest forests in eastern Africa and the richest forest in eastern Africa in terms of numbers of plant and bird species. Bwindi has the richest montane avifauna in Africa. Bwindi harbours almost a third of the world's remaining mountain gorillas, eight other species of primates, including chimps. The area is also an important water catchment;

- Kibale Forest harbours 11 species of primates including the only viable population of Uganda red colobus in the country. It has a rich bird fauna and many large mammals including elephants and buffalo. Like most forests in Uganda Kibale is managed primarily for timber production and has only a small strict nature reserve of $6,000 \mathrm{ha}$, only $11 \%$ of the total forest area. This strict nature reserve should be extended to protect more of the area's wildlife.

3. Strict nature reserves within the existing forest reserves should be managed accordingly. Species-rich forest reserves where additional nature reserves should be established are found at Semliki, Kalinzu, Kasyoha-Kitomi, Itwara, Budongo, Bugoma, Sango Bay, Mgahinga, West Mengo and Mabira. 
4. A strict nature reserve should be established in part of the Mount Elgon Forest Reserve. Large areas of the natural montane forest are being replaced by conifers and increasing agricultural settlement.

5. The Lake Opeta floodplain should be protected to conserve its abundant bird life. Other wetlands in need of protection need a review of their conservation values.

6. The open water of the freshwater lakes of Uganda are excluded from national parks and reserves, even though adjacent land has park status. This includes Lake Victoria, one of the most biologically rich lakes in the world. Major freshwater lakes include Victoria, Kyoga, Mobutu, Edward and George. This is a major omission with potentially serious consequences for aquatic flora and fauna. Consideration should thus be given to:

- Extend Murchison Falls National Park boundaries to $500 \mathrm{~m}$ offshore to include part of Lake Albert;

- Extend the boundaries of Queen Elizabeth National Park to $500 \mathrm{~m}$ of fshore to include part of the open water of Lakes Edward and George.

7. Butyrospermum moist savanna is extensive in northern Uganda and southern Sudan but is not included in any park or reserve. Surveys should be made of remaining areas of this habitat to identify a new reserve.

\section{ZAIRE}

1. Establish a reserve in the Lomako Forest to protect populations of the endangered pygmy chimpanzee, which is endemic to Zaire.

2. Establish the proposed reserves in the Marungu and Uvira Mountains to protect the montane forests and their unique wildlife as well as 300 endemic plants.

3. Establish new reserves to protect important wetlands including swamps and coastal mangroves.

4. Take action to give some protection to the important Zaire lakes, particularly Lake Tumba with its endemic fish fauna.

5. Establish a protected area in the Itombwe Mountains, an area of critical importance for montane birds. East Zaire has the richest montane avifauna in Africa with the mountains of the Albertine Rift supporting the greatest number of endemic species.

6. Management of the swamps in the Upemba region needs to be strengthened.

7. Implement recommendations for the "Okapi National Park" to protect the Okapi and a sample of its habitat in the Ituri forests. 
8. Complete the management plan for Salonga National Park as initiated at the World Heritage Mbandaka workshop.

\section{ZAMBIA}

1. Very few extensive swamps in eastern Africa are included in parks or reserves. Establish parts of the floodplains of the Zambesi River and the Bangweulu Swamp as reserves. At present these areas are included within Game Management Areas which may not give adequate protection.

2. The boundaries of the Nsumbu National Park should be extended into Lake Tanganyika to protect some of the open water of this important freshwater lake.

3. Establish reserves to protect the montane habitats of the Msuku and Mfika Hills.

4. Improve protection of Mosi-Oa-Tunya National Park which is suffering from heavy poaching. Title deeds allowing villagers to farm within the park also threaten the Park's integrity and actions concerning the situation are addressed in the new management plan for the park.

\section{ZIMBABWE}

1. Establish a reserve to protect the Parinari forests; this is already agreed.

2. Increase the protected area of endemic serpentine soil vegetation found along the Great Dyke by extending the Sebakwe Recreational Park.

3. Extend the Chimanimani National Park to include a wider area of quartz grassland and forest known to contain some endemic wildlife; abandoned proposals to establish an adjoining conservation area in Mozambique should be reconsidered.

4. Improve protection and management of Chegutu (Hartley A) Safari Area and Chipinga A Safari Area which have no management at present. Zimbabwe's Botanical Reserves have been completely neglected until recently.

5. Improve protection of Gonarezhou National Park which is under considerable pressure from poachers, from surrounding subsistence farmers who move their livestock into the park in times of drought, and from refugees from Mozambique who poach and graze their livestock in the park. 